\title{
The Use of in vitro Gas Production Technique as an Index of the Nutritive Value of Green shoot, Leaves, Fruits Flesh and Seed Cakes of Ziziphus spina-christi (Sidder) Tree for feeding Ruminants
}

\author{
Shamseldein, H .Ahmed ${ }^{1}$ :, Mohammed Eltayeb M.Jumaa², : and \\ Shadia.A., Omer ${ }^{1}$ \\ ${ }^{I}$ Department of Basic Science, College of Veterinary Medicine. Sudan University of Science and Technology. \\ Sudan. \\ ${ }^{2}$ Ministry of Defence- Military Cooperation
}

\begin{abstract}
The in vitro gas production technique was used to predict rumen fermentable organic matter, gas production kinetics, organic matter digestibility as well as metabolizable energy were evaluated in green shoot, leaves, fruits flesh and seed cakes of Ziziphus spina-christi tree. A gas production was measured by incubating samples in buffered rumen fluid from cannulated steer for $72 \mathrm{~h}$. Total gas production was recorded at 0,3, 6, 9, $12,24,48$, and $72 \mathrm{~h}$ of incubation periods and kinetics of gas production was described. The chemical analysis of these Ziziphus spina-christi parts, showed that, Leaves contained high protein $(14.77 \pm 0.23 \mathrm{~g} / \mathrm{kg})$ and green shoot less protein $(8.03 \pm 0.15 \mathrm{~g} / \mathrm{kg})$, however, high ash content was observed in green shoot $(10.03 \pm 0.07 \mathrm{~g} / \mathrm{kg})$ compare to other parts. seed cakes has the highest crude fibre content in comparison to other parts $(32.46 \pm 0.01)$, while fruits flesh contained the highest ether extract $(72.39 \pm 0.03)$. The maximum gas volume was highest for fruits flesh followed by seed cakes, green shoot and leaves after $24 \mathrm{hr}$ of incubation. In this study flesh had a significantly higher $(P<0.05)$ gas production from rapid soluble fraction $(a)$ than the other parts, while Ziziphus spina-christi leaves showed the highest gas production from slowly degradable fraction (b) .Organic matter digestibility range was (51.90- 43.79\%) and Metabolisable energy was found to be (9.16$6.74 \mathrm{MJ} / \mathrm{kgDM}$ ) in the flesh and green shoot, respectively.

It was concluded that, green shoots, leaves, fruit flesh and seed cake of Ziziphus spina-christi have the potential to be used as protein, energy and mineral supplements for ruminants especially during the dry season.

Keywords: Nabag tree, OMD, gas production kinetics.
\end{abstract}

\section{Introduction}

Animal feed contributes more than $70 \%$ of production costs (Makkar 2014).Shrubs and trees are reported to be sustainable for ruminants in the tropics and subtropical areas (Melesse 2012, Shamseldein,etal ,2013 :2014,: Basheir,etal ,2015). The tree species are important due to their high protein content, their contribution with easy fermentation carbohydrates and fiber of better degradability, as well as their positive effect on the use of nitrogen $(\mathrm{N})$ within the rumen. These elements allow to increase the productivity of animals fed with pastures (Rubanza et al. 2007). Thus, better utilization of non-agricultural by-products which do not compete with human foods is imperative. Evaluating the nutritive value of locally available unconventional sources from browse trees, legumes and seeds of trees were important as these could make an important contribution to the nutrition of livestock (Taphizadeh et al., 2008). Ziziphus spina-christi tree (Sidder) and its fruit (Nabag) indicate the importance of this plant as food. Rural population in Sudan rely on this wild growing tree species to fulfill some of some food need. Gebauer (2005) reported that Z. spina-christi is the most abundant wild fruit tree used in home gardens in El Obeid, the capital of North Kordofan state in central Sudan.

The in vitro gas production technique measures thevolume of gas produced, which reflects the end result of thefermentation of the feed substrate to volatile fatty acids (VFAs),microbial biomass and the neutralization of the VFAs produced.Determine the nutritive value of feedstuffs, since the degradation rate and extent and rumen fermentation can be easily determined by measuring cumulative gas production (Khazaal et al., 1995; Dhanoa et al., 2000; Chumpawadee et al., 2007). The in vitro gas production system helps to better quantify nutrient utilization, and its accuracy in describing digestibility in animals has been validated in numerous experiments (Taphizadeh et al., 2008).The main objective of this study was to assess the feeding values of green shoots,leaves,flesh fruit and seeds cake of $Z$. spina-christi using in vitro gas production technique. 


\section{Materials And Methods}

Study location: The study was conducted in Sudan University of Science and Technology Dairy Farm at Kuku during June 2012- Aug 2013.

Samples collection:- Samples of green shoots, fresh leaves. well -ripened fresh fruits of were randomly harvested from different Ziziphus spina christi trees grown in Khartoum State. The fleshes (mesocarp) of the fruits were separated from the seed manually; then the flesh was sun- dried, weighed and air dried under shade. The samples were then pooled for each type, ground using a laboratory mill to pass through a $1 \mathrm{~mm}$ sieve and used for determination of chemical composition.. The ground samples were labelled and kept in air tight bags until to use for the different purposes of the study.

Nutrients analysis:- Dry matter (DM) was determined by drying the sample at $105 \mathrm{c}^{\circ}$ over night and Ash by igniting the sample in muffle furnace at $525 \mathrm{c}^{\circ}$ for $8 \mathrm{hrs}$. Nitrogen $(\mathrm{N})$ content was determined by the Kjeldahl (AOAC 1990). C.P was determined as $\mathrm{N} \times 6.25$. C.F and ether extract (E.E) were determined by the methods described by the (AOAC,2006). All nutrient analyses were carried out in duplicate on each individual sample.

Gas production:- Production of gas was determined according to the procedure of Menke and Steingass (1988). About $200 \mathrm{mg}$ of feed sample from each Ziziphus spina christi tree parts was weighed in three replications and carried into calibrated glass syringes $(100 \mathrm{ml}$ - pre-warmed), fitted with Vaseline lubricated pistons. The inoculum used was the ruminal content of three steers with cannula in the rumen, fed free choice feed, water and mineral salts. Manually vacuum pump was used to collect rumen fluid and immediately transferred into prewarmed thermos flasks to the laboratory, filtered through eight layers of cheesecloth. Buffered mineral solution was added to rumen fluid with constant stirring, while maintained in a water bath at $39^{\circ} \mathrm{C}$. A total of $30 \mathrm{ml}$ incubation medium consisting of $10 \mathrm{ml}$ rumen fluid, $5 \mathrm{ml}$ of bicarbonate buffer, $5 \mathrm{ml}$ of macro-mineral solution and $10 \mathrm{ml}$ of distilled water was then dispensed into pre-warmed glass syringes containing the feed samples. After closing the clips on the silicon tube at the syringe tip, syringes were gently shaken and the clips were opened to remove gas by pushing the piston upwards to achieve complete gas removal.

After closing the clip, the initial volume was recorded and the syringes were placed in a temperature controlled incubation rotor set at $39^{\circ} \mathrm{C}$.

Three blanks containing $30 \mathrm{ml}$ of medium as well as triplicate samples of reference hay and concentrate feed of known gas production parameters were also included as standards. Incubation was completed in duplicate within each run and runs were replicated yielding four observations per sample.

Gas production was recorded before incubation (0) and 3, 6, 12, 24, 48, 72 and $96 \mathrm{~h}$ after incubation according to time pattern of Blümmel and Becker (1997). The gas produced due to fermentation of substrate was corrected by the blank syringes (containing no substrate). Cumulative gas production data were fitted to the model of Qrskov and McDonald (1979) $\mathrm{y}=\mathrm{a}+\mathrm{b}$ (1-exp ${ }^{(-\mathrm{ct})}$. where, $\mathrm{Y}$ is the volume of gas produced at time ' $\mathrm{t}$ ' $(\mathrm{ml})$; a is the gas production from the immediately soluble fraction $(\mathrm{ml})$; b is the gas production from the in soluble fraction.; $(a+b)$ the potential gas production $(\mathrm{ml})$, and $\mathrm{c}$ is the gas production ratio constant for in soluble fraction (b), (ml/hr); and $\mathrm{t}$ is the incubation time (h).

The gas produced by test substrates was corrected by the blank syringes (containing no substrate), and $24 \mathrm{~h}$ gas production was corrected by the standards for the estimation of organic matter digestibility (OMD), and metabolizable energy (ME). The ME and OMD were estimated according to Menke et al. (1979) and Menke and Steingass (1988) .

OMD $(\%)=14.88+0.889 \mathrm{GP}+0.45 \mathrm{CP}+\mathrm{XA}$

Where: -

GP IS $24 \mathrm{~h}$ net gas production $(\mathrm{ml} / 200 \mathrm{mg})$

$\mathrm{CP}=$ crude protein $(\%)$

$\mathrm{XA}=$ Ash content $(\%)$

$\mathrm{ME}(\mathrm{MJ} / \mathrm{Kg} \mathrm{DM})$ was calculated using equations of Menke et al, (1979) as follows

$\mathrm{ME}(\mathrm{MJ} / \mathrm{Kg} \mathrm{DM})=2.20+0.136 \mathrm{GP}+0.057 \mathrm{CP}+\mathrm{O} .0 \mathrm{OO} 29 \mathrm{CP}^{2}$

Where $=\mathrm{GP}$ is 24 net gas production $(\mathrm{ml} / 200 \mathrm{mg}) \mathrm{CP}=$ crude protein .

$\mathrm{ME}=$ Metabolisable energy.

$\mathrm{MJ}=$ Mega Jole.

$\mathrm{KgDM}=$

Statistical analysis: Data on nutrient compositions including calculated and estimated gas production parameters were subjected to one-way( ANOVA) analysis by using SAS software package (SAS, 2004) and differences of means were separated by Duncan multiple range test. Moreover, OMD and ME values using the General Linear Model (GLM) according of statistic, (Analytical software.2000). 
The Use of in vitro Gas Production Technique as an Index of the Nutritive Value of Green shoot, ..

\section{Results}

Nutritive composition of Ziziphus spinachristi tree parts:

The nutritive composition of the different parts of Ziziphus spina christi is shown in Table 1. In the present study, the contents of $\mathrm{CP}$, and ether extract $(\mathrm{EE})$ in leaves were significantly $(\mathrm{P}<0.05)$ higher than that of green shoots, and fruit flesh, where as the green shoots showed the lowest CP. On the other hand, fruit flesh contained significantly $(\mathrm{P}<0.05)$ higher NFE, than leaves and green shoots. However, seeds cake had significantly $(\mathrm{P}<0.05)$ higher $\mathrm{CF}$ than leaves and green shoots.

Table 1. Nutrient composition of the different parts of Ziziphus spina christi (means \pm SD)

\begin{tabular}{|l|l|l|l|l|l|l|}
\hline Part & Dry matter \% & Ether extract \% & Crude protein \% & \multicolumn{1}{|c|}{ Crude fibre\% } & $\begin{array}{c}\text { Ash\% } \\
\text { Nitrogen free } \\
\text { extract } \%\end{array}$ \\
\hline Green shoots & $96.59 \pm 0.01^{\mathrm{a}}$ & $0.3 \pm 0.0^{\mathrm{c}}$ & $8.03 \pm 0.15^{\mathrm{c}}$ & $14.21 \pm 0.012^{\mathrm{b}}$ & $10.03 \pm 0.07^{\mathrm{a}}$ & $67.43 \pm 0.3^{\mathrm{b}}$ \\
\hline Leaves & $96.15 \pm 0.0^{\mathrm{a}}$ & $1.12 \pm 0.07^{\mathrm{a}}$ & $14.77 \pm 0.23^{\mathrm{a}}$ & $12.72 \pm 0.01^{\mathrm{c}}$ & $8.47 \pm 0.12^{\mathrm{b}}$ & $62.92 \pm 0.22^{\mathrm{b}}$ \\
\hline Fruit Flesh & $94.61 \pm 0.01^{\mathrm{b}}$ & $0.94 \pm 0.01^{\mathrm{b}}$ & $10.55 \pm 0.07^{\mathrm{b}}$ & $13.50 \pm 0.01^{\mathrm{b}}$ & $2.62 \pm 0.01^{\mathrm{c}}$ & $72.39 \pm 0.03^{\mathrm{a}}$ \\
\hline Seed cake & $94.63 \pm 0.01^{\mathrm{b}}$ & $1.09 \pm 0.01^{\mathrm{a}}$ & $8.65 \pm 0.08^{\mathrm{c}}$ & $32.46 \pm 0.01^{\mathrm{a}}$ & $3.12 \pm 0.01^{\mathrm{c}}$ & $54.68 \pm 0.47^{\mathrm{c}}$ \\
\hline SEM & 3.19 & 0.15 & 1.32 & 1.89 & 1.62 & 2.202 .20 \\
& & & & & $*$ & $*$ \\
\hline Sig & $*$ & $*$ & $*$ & $*$ & $*$ \\
\hline
\end{tabular}

Means within the same column with different superscripts are significantly different $(\mathrm{P}<0.05)$.

\section{In vitro gas production, calculated and estimated parameters}

The in vitro gas production for the different parts of Ziziphus spina christi at different incubation periods is present in Figure 1. The highest gas production was observed in the flesh, while the leaves showed the lowest gas production during all the incubation times.

Table (2) shows the parameters estimated from the gas production of Ziziphus spina christi parts. Soluble fraction (a) was significantly different between the fruit flesh and Seed cake, while no significant difference was observed between the green shoot and leaves, The highest soluble fraction was observed in the Seed cake. Gas production from the slowly degradable fraction (b) varied significantly between the different parts of the tree, and the Leaves showed the highest value. Rate of gas production (c) varied significantly $(\mathrm{P}<0.05)$ among the different parts of Ziziphus spina christi. Highest organic matter digestibility (OMD) and metabolizable energy values were detected in fruit flesh of Ziziphus spina christi.

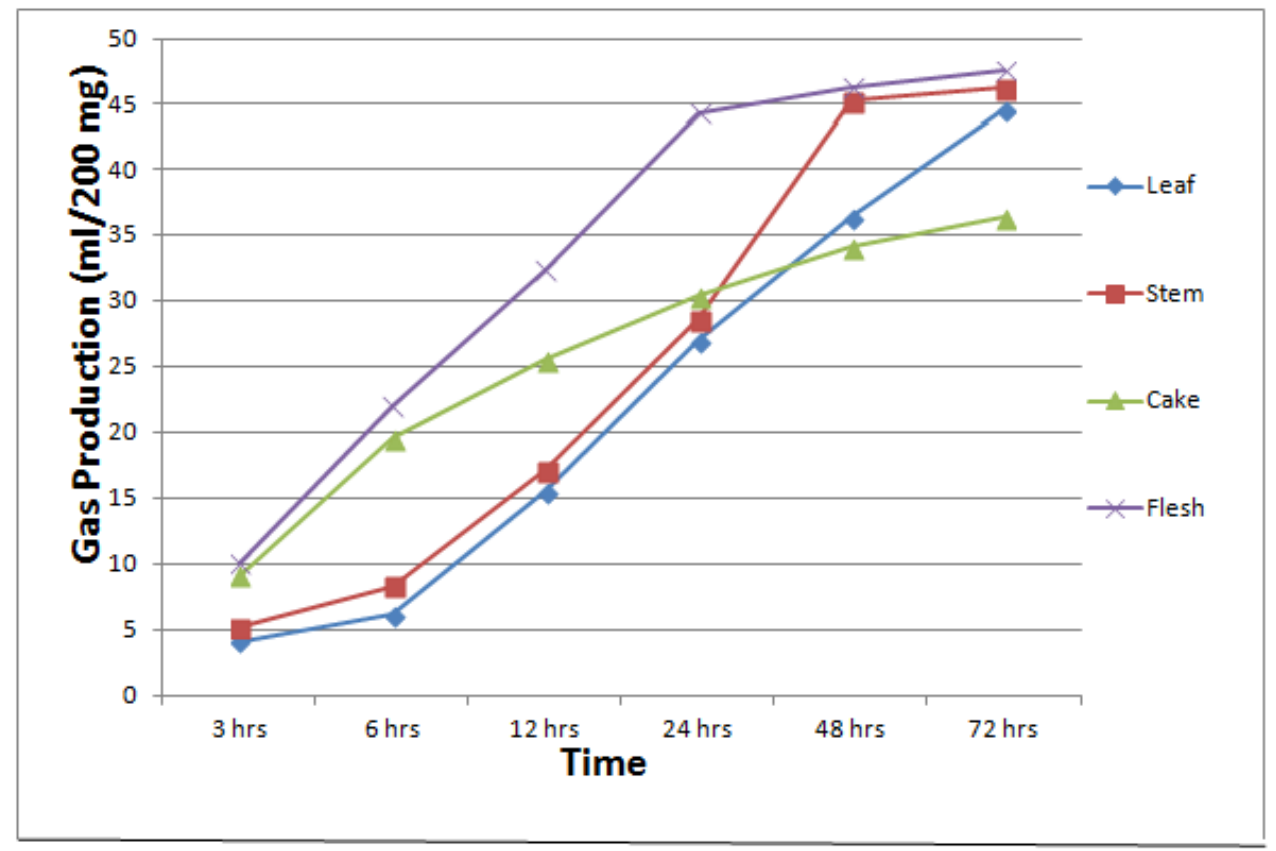

Figure (1) Data of gas production during the incubation period

Leaves of Ziziphus spina christi.

Coat of Ziziphus spina christi

Flesh of Ziziphus spina christi

Kernel cake of Ziziphus spina christi 
The Use of in vitro Gas Production Technique as an Index of the Nutritive Value of Green shoot, ..

Table 2. Parameters estimated from the gas production of Ziziphus spina christi parts

\begin{tabular}{l|c|c|c|c|c|c}
\hline Part & $\mathrm{a}$ & $\mathrm{b}$ & $\mathrm{a}+\mathrm{b}$ & $\mathrm{c}$ & $\mathrm{OMD}$ & $\mathrm{ME}$ \\
\hline Green shoots & $-0.8905^{\mathrm{b}}$ & $70.0096^{\mathrm{b}}$ & $69.12^{\mathrm{b}}$ & $0.01263^{\mathrm{b}}$ & $43.79^{\mathrm{b}}$ & $6.74^{\mathrm{c}}$ \\
leaves & $-0.6187^{\mathrm{b}}$ & $75.5412^{\mathrm{a}}$ & $74.92^{\mathrm{a}}$ & $0.00949^{\mathrm{c}}$ & $43.87^{\mathrm{b}}$ & $7.35^{\mathrm{b}}$ \\
flesh & $-3.4245^{\mathrm{c}}$ & $51.1836^{\mathrm{c}}$ & $47.609^{\mathrm{c}}$ & $0.05331^{\mathrm{a}}$ & $51.90^{\mathrm{a}}$ & $9.16^{\mathrm{a}}$ \\
Seed cake & $1.10906^{\mathrm{a}}$ & $33.9781^{\mathrm{d}}$ & $32.691^{\mathrm{d}}$ & $0.05393^{\mathrm{a}}$ & $44.62^{\mathrm{b}}$ & $7.06^{\mathrm{b}}$ \\
SEM & 0.54 & 3.47 & 4.81 & 0.01 & 2.50 & 0.03 \\
\hline
\end{tabular}

Means within the same column with differencing superscripts are significantly different.

$\mathrm{a}=$ the gas production from the immediately soluble fraction $(\mathrm{ml})$,

$\mathrm{b}=$ the gas production from the insoluble fraction $(\mathrm{ml})$.

$\mathrm{c}=$ the gas production rate constant from the insoluble fraction $(\mathrm{b})$.

$a+b=$ Potential gas production.

$\mathrm{ME}=$ Metabolisable energy

$\mathrm{OMD}=$ Organic matter digestibility

SEM: standard error of means

\section{Discussion}

The obtained results from this study coincide with the other studies with shrubs and trees (García et al. 2008, Edwards et al. 2012 and Aye and Adegun 2013).The average CP content of leaves in the present study is similar to CP content of Morus alba ,(Kamalak etal,2004), Guava leaf(Psidium guajava) and high than CP of Mango leaf (Mangifera indica) and Mehgoni leaf (Swietenia macrophylla) (Uddin, etal,2015), and lower than the CP of Leaves of Growia tenaxthae,( Basheir,etal ,2015), Moringa. stenopetala (Gebregiorgis et al. (2011: Negesse et al. (2009) and Melesse et al. (2011), Moringa oleifera leaves,(Moyo et al. 2011) , Morus alba leaves ,( Liu et al (2001) : Phiny et al (2003), Balanite aegyptiaca (Shamseldein, 2011), mulberry (Morus alba Linn), trichanthera (Trichanthera gigantea) and leucaena (Leucaena leucocephala). (Rodríguez,etal 2014). Neem leaf (Azadirachta indica) ),( Uddin, etal,2015),. Although there is a wide variation in the values found in the literature, probably due to the effect of the parts of collected plants, their phenological state, season in which it was collected, cut frequency and environment where collected material was developed, and age of leaves at harvest, soil type and fertility, (Edwards et al. 2012).The NFE in Ziziphus spina christi flesh and leaves of the present study is higher than that of Balanite aegyptiaca flesh and leaves (Shamseldein, 2011).The CP content in seeds cake is lower than seed cake of Balanite aegyptiaca (Shamseldein, 2009), Tabaldi Seed Cake (Adansoniadigitata), (Randa 2012). The crude fiber contents in leaves are comparable to those reported by Gebregiorgis et al. (2011) for M. stenopetala leaves but lower than the values reported by Sanchez et al. (2006) for $M$. oleifera leaves. The crude fiber values found in seeds cakeare considerably higher than those reported for Balanite aegyptiaca, (Shamseldein, 2009), Tabaldi Seed Cake (Adansoniadigitata), (Randa 2012). The high contents of fibrous substances in seeds cakes, may affect the dry matter intake by ruminants. The fact that seeds cake contained $>50 \% \mathrm{NDF}$ indicate that they may have only fair proportions of soluble carbohydrate which is helpful to maintain a proper rumen function (Oni et al., 2008).The ash content of Ziziphus spina christi is lower than that of Morus alba,(Kamalak etal,2004),

\section{In vitro fermentation, calculated and estimated parameters}

In the present study, the highest gas production was observed in the flesh, while the leaves showed the lowest gas production during all the incubation time.The gas production from flesh is slightly higher than that reported by Balanite aegyptiaca (Shamseldein, 2011). However, the in vitro gas obtained from leaves in the current study was considerably higher than that reported by Oni et al. (2010) for four Cassava varieties. The high gas production of flesh in this study was recorded ,similar results were obtained by Morkaz,etal(2011),is that flesh of Balanite aegyptiaca showed the highest gas production at all the time of incubation,this may be attributed to its low content of CF and its high content of easy fermentation carbohydrates. Meanwhile, the low gas productions of seed cake after 24 hours may be related with its high fiber contents (Delgado et al. 2007). The lowest potential of gas production of leaves before 24 hours may be related to its high levels of CP, because the protein contributes less to gas production than carbohydrates. It is known that the level of CP in a substratum 
The Use of in vitro Gas Production Technique as an Index of the Nutritive Value of Green shoot, ..

is negatively correlated to gas production resulting from its in vitro fermentation (Getachew et al. 2004) .Values of gas produced from soluble fractions (parameter a) from green shoots, leaves, fruit flesh and seeds cake was generally lower than $t$ those reported by Morkaz et al. (2011) for green shoots, leaves, fruit flesh and seeds-cake of Balanite aegyptiaca tree. The value of "a" for seed cake was comparatively higher than leaves and green shoots suggesting an early onset of fermentation and microbial attachment to this particular feed material. The average gas production from insoluble but with time fermentable fraction (parameter $b$ ) for green shoot and leaves was higher than the findings of Morkaz et al. (2011) for Balanite aegyptiaca. Rate of fermentation (parameter c) obtained from flesh and seed cake in the present study is in good agreement with the findings of Morkaz et al. (2011). High fermentation rates indicates high nutrient availability for ruminal microorganisms; while lower fermentation rate values may be the result of greater CF content, whose chemical components could slow down substrate fermentation speed (Fievez et al., 2005). Metabolizable energy for leaves is lower than reported by Anele et al. (2009) for leaves of tropic multi-purpose trees. The OMD values obtained from leaves in the current study are lower than the findings of Murillo et al. (2011)and .( Morkaz,etal ,2011).

\section{Conclusion}

In conclusion, the chemical compositions, in vitro gas production parameters and calculated metabolizable energy, organic matter digestibility that, leaves can be used as potential supplement sources of protein, whereas, fruit flesh and seed cake can be used as source of energy and green shoot as source of minerals in ruminant feeding in the Sudan.

\section{Acknowledgements}

The authors would like to acknowledge the Scientific Research Deanship- Sudan University of Science and Technology for funding money, research facilities to run this study successfully.

\section{Reference}

[1]. Anele UY, Arigbede OM, Südekum KH, Oni AO, Jolaosho AO, Olanite JA, Adeosun AI, Dele PA, Ike KA Akinola OB (2009). Seasonal chemical composition, in vitro fermentation and in sacco dry matter degradation of four indigenous multipurpose tree species in Nigeria. Anim. Feed Sci. Technol. 154: 47-57.

[2]. AOAC.(2006). Official Methods of Analysis, 16th edition. Association of Official Analytical Chemists, Washington, DC, 2006

[3]. Aye, P.A. \& Adegun, M.K. (2013). Chemical composition and some functional properties of moringa, leucaena and gliricidia leaf meals. Agric. Biol. J. North America 4: 71

[4]. Basheir, E. 1, Shamseldein, H. Ahmed and Shadia A. Omer .(2015).Degradability Characteristics of Dry Matter and Crude Protein of Growia tenax Using the in situ and in vitro Techniques in Ruminants -Sudan Journal of Science and Technology (2015) 16(1): 68-75

[5]. Blümmel M, and Becker K (1997). The degradability characteristics of fifty-four roughages and roughage neutral-detergent fibres as described by in vitro gas production and their relationship to voluntary feed intake. Br. J. Nutr. 77: 757-768.

[6]. Chumpawadee S., Chantiratikul A. and Chantiratikul P., (2007). Chemical composition and Nutritional evaluation of energy feeds for ruminant using in vitro gas production technique. Pakistan Journal of Nutrition 6(6):607-612, 2007.

[7]. Delgado, D.C., González, R., Galindo, J., Cairo, J. \& Almeida, M. (2007. Potential of Trichantera gigantea and Morus alba to reduce in vitro rumen methane production. .Cuban J. Agric. Sci. 41: 319

[8]. Dhanoa M.S., Lopez S. and Dijkstra J.(2000)., Estimating the extent of degradation of ruminant feeds from a description of their gas production profiles observed in vitro: Comparison of models. British Journal of Nutrition 83: 131- 142, 2000.

[9]. Edwards, A., Mlambo, V., Lallo, C.H.O. \& García, G. W.(2012). Yield, chemical composition and in vitro ruminal fermentation of the leaves of Leucaena leucocephala, Gliricidia sepium and Trichanthera gigantea as influenced by harvesting frequency. J. Anim. Sci. Adv.(Suppl. 3.2): 321

[10]. Fievez V, Babayemi OJ, Demeyer D (2005). Estimation of direct and indirect gas production in syringes: A tool to estimate short chain fatty acid production that requires minimal laboratory facilities. Anim. Feed Sci. Technol. 123-124: 197-210

[11]. García, D.E., Medina, M.G., Cova, L.J., Torres, J., Soca, M., Pizzani, P., Baldizán, A. \& Domínguez, C.E(.2008). Preferencia de vacunos por el follaje de doce especies con potencial para sistemas agrosilvopastoriles en el Estado Trujillo, Venezuela. Pastos y Forrajes 31: 255

[12]. Gebauer J (2005) Plant species diversity of home gardens in ElObeid, central Sudan. JARTS 106:97-103.

[13]. Gebregiorgis F, Negesse T, Nurfeta A (2011). Feed intake and utilization in sheep fed graded levels of dried moringa (Moringa stenopetala) leaf as a supplement to Rhodes grass hay. Trop. Anim. Health Prod. (In press) DOI 10.1007/s11250-011-9927-9.

[14]. Getachew, G., Robinson, P.H., DePeters, E.J. \& Taylo, S.J. 2004. Relationships between chemical composition, dry matter degradation and in vitro gas production of several ruminant feeds. Anim. Feed Sci. Technol.111: 57

[15]. Kamalak, A . Canbolat O, Gurbuz, Y Ozay, O, Ozkan O and Sakarya M.(2004).Chemical composition and in vitro gas production characteristics of several tannin containing tree leaves. Livestock Research for Rural Development 16 (6) 2004

[16]. Khazaal K., Dentinho M.T., Ribeiro J.M. and Orskov E.R. (1995.)., Prediction of apparent digestibility and voluntary feed intake of hays fed to sheep: Comparison between using fibre component, in vitro digestibility or characteristics of gas production or nylon bag degradation. Journal of Animal Science 61: 521-538, 1995.

[17]. Liu J X, Yao J, Yan B, Yu, J Q and Shi Z Q (2001). Effects of mulberry leaves to replace rapeseed meal on performance of sheep feeding on ammoniated rice straw diet. Small Ruminant Research, 39: 131-136

[18]. Makkar, H.P.S. (2014). Sustainable increase in livestock productivity in developing countries through efficient utilization of feed resources. Cuban J. Agric. Sci. 48: 55

[19]. Melesse, A. (2012). Assessing the feeding values of leaves, seeds and seeds-removed pods of Moringa stenopetala using in vitro gas production technique. African J. Biotechnol. 11: 11342. 
The Use of in vitro Gas Production Technique as an Index of the Nutritive Value of Green shoot, ..

[20]. Menke KH, Raab L, Salewski A, Steingass H, Fritz D, Schneider W (1979). The estimation of the digestibility and metabolizable energy content of ruminant feeding stuffs from the gas production when they are incubated with rumen liquor in vitro. J. Agric. Sci. Camb. 93: 217-222.

[21]. Menke KH, Steingass $\mathbf{H}$ (1988). Estimation of the energetic feed value obtained from chemical analysis and gas production using rumen fluid. Anim. Res. Dev. 28: 7-55.

[22]. Morkaz M. G : Shamseldein.H,.Ahmed:, and Shadia.A. Omer , (2011).Chemical composition, in vitro gas production, metabolizable energy and organic matter digestibility of leaves and seed fractions of the tree Balanite aegyptiaca. Assiut .Vet. Med. Journal. July. 2011. Vol. 57. No. 130. Pp. 284-294.

[23]. Moyo B, Masika JP, Hugo A, Muchenje V (2011). Nutritional characterization of Moringa (Moringa oleifera Lam.) leaves. Afr. J. Biotechnol. 10(60): 12925-12933.

[24]. Murillo M, Herrera E, Reyes O, Gurrola JN, Gutierrez E (2011). Use of in vitro gas production technique for assessment of nutritional quality of diets by range steers. Afr. J. Agri. Res. 6(11): 2522-2526.

[25]. Negesse T, Makkar HPS, Becker K (2009). Nutritive value of some non-conventional feed resources of Ethiopia determined by chemical analyses and an in vitro gas method. Anim. Feed Sci. Technol. 154: 204-217

[26]. Oni AO, Onwuka CFI, Arigbede OM, Anele UY, Oduguwa OO, Onifade OS, Tan ZL (2008). Utilization of citrus based diets and Enterolobium cyclocarpum (JACQ GRISEB.) foliage by West African dwarf goats. Livestock Sci. 117: 184-191.

[27]. Oni AO, Onwuka CFI, Arigbede OM, Anele UY, Oduguwa OO, Onifade OS Tan ZL (2010). Chemical composition and nutritive value of four varieties of cassava leaves grown in South-Western Nigeria. J. Anim. Physiol. Anim. Nutr. 95: 583-590.

[28]. Ørskov, E.R. and McDonald, I. (1979). The estimation of proteindegradation in the rumen from incubation measurements weightedaccording to the rate of passage. J. Agric. Sci. 92:499-503.

[29]. Phiny C, Preston T R and Ly J( 2003). Mulberry (Morus alba) leaves as protein source for young pigs fed rice-based diets: Digestibility studies. Livestock Research for rural development. 15 (1), 2003. http://www.cipav.org.co/lrrd//rrd15/1/phin151.htm

[30]. Randa ,A.B,: Shamseldein, H .Ahmed and Shadia.A., Omer (2012). In Situ Ruminal Dry Matter and Crude protein Degradability of Tabaldi Seed Cake (Adansoniadigitata), Sudan. Sud.J of Vet Med.and Anim. Husb. . (2012). Vol.52. Pp. 91-99

[31]. Rodríguez, R. González, N, Alonso, J. Domínguez M, and Sarduy L.(2014).Nutritional value of foliage meal from four species of tropical trees for feeding ruminants. Cuban Journal of Agricultural Science, Volume 48, Number 4, 2014. 371

[32]. Rubanza, C.D.K., Shem, M.N., Bakengesa, S.S., Ichinohe, T. \& Fujihara, T. (2007). Effects of Acacia nilotica, Acacia polyacantha and Leucaena leucocephala leaf meal supplementation on performance of Small East African goats fed native pasture hay basal forages. Small Ruminant Res. 70:165.

[33]. Sanchez NR, Ledin S, Ledin I (2006). Biomass production and chemical composition of Moringa oleifera under different management regimes in Nicaragua. Agroforest. Syst. 66: 231-242

[34]. SAS, Statistical Analysis System (2004). Ver. 9.0. SAS Institute Inc. Cary North California, USA.

[35]. Shamseldei H Ahmed, M.G. Morkaz :Shadia,A. O.; (2011). Evaluation of Balanite aegyptiaca;leaves,seed kernel cake, fruit coat and flesh as ruminant feed. Assiut .Vet. Med. Journal. Jan. 2011. Vol. 57. No. 128. Pp. 11-22.

[36]. Shamseldein .H. Ahmed., Shadia .A. Omer, Eldow. M.Y:, Ali A. S., Sakata T. and Nawata4.( 2013).Effect of Feeding Rations Containing Different Levels of Mesquite Pods on growth and Carcass Characteristics of Sudanese Nubian Goats. European International Journal of Science and Technology Vol. 2 No. 9 November, 2013-237.

[37]. Shamseldein, H .Ahmed1, Shadia.A., Omer2 (2014).Rumen Degradation and Nutritive Value of Fruit Flesh Seed Cake, Leaves and Green Shoots of Sidder (Ziziphus Spina-Christi) Trees. International Journal of Novel Research in Civil Structural and Earth Sciences Vol. 1, Issue 1, pp: (46-52

[38]. Taphizadeh A., Palangi A. and Safamehr A. (2008.)., Determining nutritive value of Alfalfa cuts using in situ and gas production techniques.Journal of Animal and Veterinary Science 3(3):85-90, 2008.

[39]. Uddin MJ, Khandaker ZH and Khan1 MJ.(2015).Nutritive Values and Chemical Composition ofFoliages, Grass and HerbsUsing in vitro Technique.ISESCO JOURNAL of Science and Technology,Volume 11 - Number 20 - November 2015 (35-43) 